\title{
Response of mycorrhizal grapevine to Armillaria mellea inoculation: disease development and polyamines
}

\author{
Amaia Nogales • Jone Aguirreolea • \\ Eva Santa María • Amèlia Camprubí • \\ Cinta Calvet
}

Received: 25 June 2008 / Accepted: 2 October 2008 / Published online: 23 October 2008

(C) Springer Science + Business Media B.V. 2008

\begin{abstract}
A study was conducted with the vine rootstock Richter 110 (Vitis berlandieri Planch. x Vitis rupestris L.) in order to assess whether the colonisation by the arbuscular mycorrhizal fungus (AMF) Glomus intraradices (BEG 72) can delay the disease development in plants inoculated with the root-rot fungus Armillaria mellea (Vahl:Fr) Kummer, and to elucidate if the levels of polyamines (PAs) are modified in response to G. intraradices, A. mellea or by the dual infection. Four treatments were considered: control and $G$. intraradices-inoculated plants infected or not with A. mellea. Plant growth, mycorrhizal colonisation and disease development were monitored throughout the experiment. High performance liquid chromatography (HPLC) in combination with fluorescence spectrophotometry was used to separate and quantify free root and leaf polyamines. The slower development of pathogenic symptoms and the higher plant biomass of mycorrhi-
\end{abstract}

Responsible Editor: Harsh P. Bais.

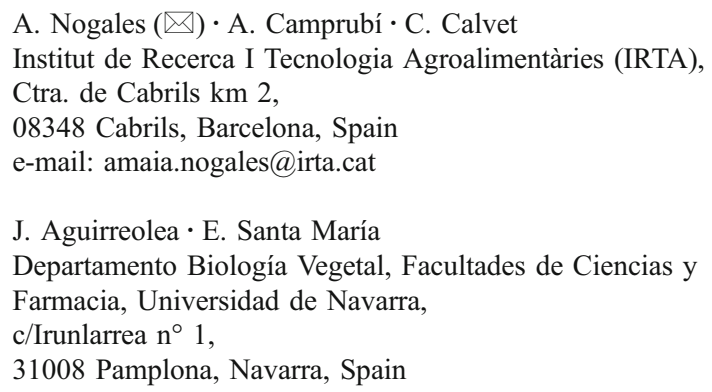

zal plants inoculated with $A$. mellea indicate an increase of tolerance due to the AMF inoculation. The variations in free PA levels detected at the beginning of the pathogenic infection suggest that PAs may have a potential role in the signalling mechanisms of the tolerance of mycorrhizal plants against $A$. mellea.

Keywords Polyamines - Arbuscular mycorrhizae . White root rot disease - Grapevine - Bioprotection · Stress-tolerance

\section{Introduction}

Armillaria mellea (Vahl:Fr.) P. Kummer, is the causal agent of Armillaria white root rot disease of grapevine (Vitis vinifera L.). The fungus infects woody grapevine roots and the underlying vascular tissues, resulting in a slow decline and eventual death of the vine (Agrios 2005; Baumgartner 2004). The control of A. mellea is difficult because of its high infection capacity, and its long-term survival in the soil. The eradication of fungal infection sources from vineyard soils is not an easy task due to the saprobic behaviour of the fungus, the presence of rhizomorphs, the infection of subterranean organs and the mycelium growth under the bark (Aguín-Casal et al. 2006).

Environmentally based restrictions on pesticides indicate the need to consider other alternatives of cultural or biological origin in order to alleviate the 
disease symptoms or to improve productivity of already infested vineyards (Baumgartner et al. 2005; Fox 2003). Biological control of A. mellea is also difficult to implement because the pathogen occupies a wide space in the soil, and once the plant is infected, antagonistic microorganisms are usually not able to eradicate the pathogen; they can only decrease its colonisation level and limit the pathogen's food base (Baumgartner and Warnock 2006; Rishbeth 1976).

It has been observed that grapevines are dependent on arbuscular mycorrhizal fungi (AMF) (Menge et al. 1983) and several authors have reported beneficial effects of mycorrhizal inoculation of grapevines (Aguín et al. 2004; Camprubí et al. 2008; Cheng and Baumgartner 2006; Karagiannidis et al. 2007; Nikolaou et al. 2003). Once the symbiosis is established with the host plant, AMF are able to confer tolerance against root pathogens (Calvet et al. 1995; Pozo et al. 2002), and it has been observed that mycorrhizal grapevines are more tolerant to various root diseases ( $\mathrm{Li}$ et al. 2006; Waschkies et al. 1994). Concerning the white root rot disease, Aguín-Casal et al. (2006) observed that inoculation of vine with the AMF Glomus aggregatum (Schenck \& Smith) resulted in a reduced disease index of $A$. mellea in several vine rootstocks.

Different mechanisms have been shown to play a role in plant protection by AMF, as improved plant nutrition, damage compensation, competition for colonisation sites and photosynthates, changes in the root system, changes in rhizosphere microbial populations and activation of plant defence mechanisms. It has been observed that several of those mechanisms can be operative simultaneously (Azcón-Aguilar et al. 2002). In addition, AMF could elicit localized defence responses in colonised tissues and systemic responses in non-colonised tissues of mycorrhizal plants (Azcón-Aguilar et al. 2002; Khaosaad et al. 2007; Liu et al. 2007).

Polyamines (PA) are small polycationic compounds which are ubiquitous in all living organisms (Alcázar et al. 2003). The most abundant polyamines in plant tissues are putrescine and spermidine, whereas spermine is found in lower or even in trace concentrations. Polyamines are implicated in a variety of developmental processes in higher plants, and they also have a significant role in plant defence and adaptation to various abiotic or biotic stress conditions (Ndayiragije and Lutts 2007; Alcázar et al.
2003; Bouchereau et al. 1999; Kaur-Sawhney et al. 2003; Walters 2000). Polyamines are also implicated in molecular signalling events in plant pathogen interactions (Martin-Tanguy 1987; Whipps et al. 1982).

The changes in plant PA metabolism detected during pathogenic fungal infections also suggest that they could be involved in other plant-fungal interactions such as the mycorrhizal symbiosis (LudwigMüller 2000). However, few data are available on the role of PAs in plant microbe symbiosis, especially in mycorrhizal associations - the sole report that we are aware of having been the demonstration that externally applied PAs increased the frequency of AMF colonisation in pea (El Ghachtouli et al. 1995).

The mechanisms by which PAs affect arbuscular mycorrhizal symbiosis could be by the involvement in signalling events in the plant-fungus interaction; by acting directly on the fungus through the contact events with host roots or by altering host plant physiology (e.g. interacting with pectinases) thus affecting adhesion and/or penetration of the plant cell wall by the AMF.

It has also been suggested that PAs may be involved in the acquisition of resistance against plant pathogens (Angellini et al. 1993; Guo et al. 1999; Wróbel-Kwiatkowska et al. 2004), but there is no information available on the implication of PAs in the mycorrhizal symbiosis induced tolerance against pathogens.

Therefore, the first objective of this work was to assess whether AMF can delay the development of Armillaria white root-rot disease in vine, and the second one was to know if the levels of main PAs are modified in response to Glomus intraradices Schenk $\&$ Smith, A. mellea or by the dual infection.

\section{Material and methods}

Biological material, growth conditions and inoculation methods

The study was conducted with the vine rootstock Richter 110 (Vitis berlandieri Planch. x Vitis rupestris L.) under greenhouse and shadowhouse conditions. Richter 110 (R-110) is well adapted to drought and to the high lime content soils of Eastern Spain, and this rootstock is known to have a good response to AMF 
colonisation (Camprubí et al. 2008). Hardwood cuttings, $20-30 \mathrm{~cm}$ long were disinfected during $15 \mathrm{~min}$ in $0.1 \%$ oxyquinoleine sulphate solution and dipped in the rooting mix Inabarplant IV $^{\circledR}$ (AIB $0.4 \%$, ANA $0.4 \%$ and Captan 15\%). Cuttings were planted into Perlite TM rooting beds in a greenhouse $\left(25-18^{\circ} \mathrm{C}\right.$ day/night), and watered daily until root emergency and sprouting (Camprubí et al. 2008).

Six weeks later, homogeneous cuttings were transplanted into 21 containers filled with a pasteurized mixture of sandy soil, quartz sand and sphagnum peat substrate $(3: 2: 1 \mathrm{v} / \mathrm{v})$; P content $(8 \mathrm{mg} / \mathrm{kg})$. Plants were divided into two groups of 80 plants each: (1) non mycorrhizal plants (NM) and (2) mycorrhizal plants (M) inoculated with $G$. intraradices, registered in the European Bank of Glomales as BEG 72. The inoculum consisted of Allium porrum L. mycorrhizal roots and fungal propagules in Terragreen (Oil-dri Company, UK). The concentration was 114 propagules in $100 \mathrm{ml}$ Terragreen, and $20 \mathrm{ml}$ of inoculum were applied both upon and under the plantlet root system.

Fourteen week old plants were transplanted into 3.51 containers filled with the same substrate mixture and moved to a shadowhouse. Two weeks later, $40 \mathrm{M}$ and $40 \mathrm{NM}$ plants were inoculated with an isolate of A. mellea obtained from a naturally infested vineyard in Vimbodí (Tarragona, Spain). The inoculum was produced following the method described by Beckman and Pusey (2001) and consisted of Quercus suber L. infected acorns, two per plant, introduced into the soil mixture near the vine roots at $10 \mathrm{~cm}$ deep. Plants were weekly fertilized with $100 \mathrm{ml} \mathrm{P}$ deficient Hoagland nutrient solution, all along the growing season.

Four sampling dates were established from July to March 2006, corresponding with 4, 5, 7 and 12 months after AM inoculation and 3 weeks, 2, 3 and 9 months after A. mellea inoculation respectively
(Table 1). The final harvest was made at the end of the second growing year (October 2006).

Disease assessment and estimation of AMF colonisation

Disease severity was non-destructively estimated in 12 plants per treatment, during the second growing season, as percentage of plants showing necrotic zones in root and root collar. The presence of the fungus was confirmed by molecular techniques with specific primers as described by Aguín (2001).

The percentage of AMF root colonisation was estimated in three plants per treatment at the same sampling dates as for PA analysis by using the gridline intersect method (Giovannetti and Mosse 1980). Root samples were stained previously with the method described by Koske and Gemma (1989).

In July 2006, leaf relative chlorophyll content was recorded with a chlorophyll meter (Chlorophyll Meter SPAD 502, Minolta corp. N. J. EUA). Five measurements were done in each of the 12 plants from each of the four treatments.

At the end of the first growing season (September 2005) and in April, August and October of the second growing season (2006) plant biomass production (shoot dry weight) was measured in 12 plants. Additionally at harvest, in October 2006, the root biomass (dry weight) was also recorded.

Polyamine analysis

Roots and leaves for PAs analysis were collected, quickly frozen in liquid nitrogen and stored at $-80^{\circ} \mathrm{C}$ until analysis. HPLC in combination with fluorescence spectrophotometry was used to separate and quantify PAs (Flores and Galston 1982; Geny et al. 1997). PAs extraction from leaves (1 g) and roots (69 g) samples was done following the Flores and

Table 1 Sampling dates since inoculation of Richter 110 vines with Glomus intraradices and Armillaria mellea

\begin{tabular}{llll}
\hline & Time since inoculation with G. intraradices (months) & Time since inoculation with A. mellea & Sampling date \\
\hline 1st sampling & 4 & 3 weeks & July 2005 \\
2nd sampling & 5 & 2 months & August 2005 \\
3rd sampling & 7 & 3 months & September 2005 \\
4th sampling & 12 & 9 months & March 2006 \\
Final harvest & 18 & 15 months & October 2006 \\
\hline
\end{tabular}


Galston (1982) method modified by Geny et al. (1997). Roots were previously homogenized in liquid nitrogen and macerated in $1 \mathrm{~N} \mathrm{HCl}$ for $48 \mathrm{~h}$. The rest of the extraction process was done following the same methodology as for leaf samples.

Results correspond to the mean and standard deviation from triplicate samples and are expressed as nanomoles of PA per gram dry matter.

\section{Statistical analysis}

A two way analysis of variance (ANOVA) was performed in order to consider the variance into the main effects and the interaction between the two factors. Means \pm standard errors, SE $(n=3$ plants per treatment for polyamines and mycorrhizal colonisation percentage, and $n=12$ plants per treatment for biomass and relative chlorophyll content) were calculated and, when the $F$ ratio was significant, least significant differences were analyzed by the Duncan test. The statistical program used was SAS System for Windows V.8.0.

\section{Results}

Disease assessment and estimation of AM fungal colonisation

Symptoms of disease in the pathogen-inoculated plants appeared at the second growing year. Although no fungal mycelium was visible in necrotic zones, molecular techniques confirmed the presence of $A$. mellea. Twelve months after the inoculation with the pathogen (July 2006), the percentage of NM plants inoculated with A. mellea and with pathogenic symptoms (collar root necrosis and root necrosis) doubled the percentage of M-A. mellea inoculated plants, and whereas $8 \%$ of NM plants already died, none of the plants from the MA. mellea inoculated treatment died (Table 2). Three months later, in October 2006, the percentage of plants with visible symptoms of disease was slightly higher in NM plants inoculated with the pathogen, $56 \%$ versus $42 \%$. Moreover, $15 \%$ of those plants had already died while all plants survived in the M-A. mellea treatment (Table 2).

Plants inoculated with $A$. mellea had a significantly lower foliar chlorophyll content, although inoculation with $G$. intraradices alleviated the decrease attributed to the pathogenic fungus (Table 2).

No significant differences were detected in shoot dry matter between treatments at the end of the first growing year, in September 2005. From May 2006 onwards $\mathrm{M}$ plants had significantly higher biomass records, both shoot and root dry weights (Table 3). The deleterious effect of $A$. mellea on shoot dry matter was not detected until August 2006. From August to October 2006, the growth decrease due to the pathogenic infection was lower in mycorrhizal plants, which were not different from control plants.

The percentage of mycorrhizal colonisation was between $40 \%$ and $50 \%$ in both $\mathrm{M}$ treatments, inoculated or not with $A$. mellea at the first sampling date (July 2005). The symbiosis was well established (70-75\%) from August 2005 onwards, 5 months after AMF inoculation, and no significant differences were found between treatments (Table 4).

Free polyamines

Root and leaf polyamine concentration differed according to treatment and stage of development. In

Table 2 Pathogenic symptoms in Richter 110 vines measured in July and October of the second growing season (2006) and relative chlorophyll content in July 2006

\begin{tabular}{|c|c|c|c|c|c|c|c|}
\hline \multirow[t]{2}{*}{ Treatment } & \multicolumn{2}{|c|}{$\begin{array}{l}\text { Collar root necrosis } \\
\text { ( } \% \text { of plants) }\end{array}$} & \multicolumn{2}{|c|}{$\begin{array}{l}\text { Root necrosis } \\
\text { (\% of plants) }\end{array}$} & \multicolumn{2}{|c|}{ Dead plants $(\%)$} & \multirow{2}{*}{$\begin{array}{l}\text { Relative chlorophyll content } \\
\text { July }\end{array}$} \\
\hline & July & October & July & October & July & October & \\
\hline Control & 0 & 0 & 0 & 0 & 0 & 0 & $27.1 \mathrm{a}$ \\
\hline G. intraradices & 0 & 0 & 0 & 0 & 0 & 0 & $26.3 \mathrm{a}$ \\
\hline A. mellea & 68 & 56 & 43 & 56 & 8 & 15 & $23.7 \mathrm{~b}$ \\
\hline G. intraradices + A. mellea & 31 & 42 & 23 & 42 & 0 & 0 & $25.6 \mathrm{ab}$ \\
\hline
\end{tabular}

${ }^{a}$ Different letters indicate significant differences $(p=0.05)$ according to Duncan's test 
Table 3 Biomass production (shoot and root dry weights) at the end of the first growing year, and in May, August and October of the second growing year in mycorrhizal and non mycorrhizal vines inoculated or not with Armillaria mellea

\begin{tabular}{|c|c|c|c|c|c|}
\hline \multirow[t]{2}{*}{ Treatment } & \multicolumn{4}{|c|}{ Shoot dry matter (g) } & \multirow{2}{*}{$\frac{\text { Root dry matter }(\mathrm{g})}{\text { October } 2006}$} \\
\hline & September 2005 & May 2006 & August 2006 & October 2006 & \\
\hline Control & $4.47 \mathrm{a}$ & $3.86 \mathrm{~b}$ & $9.05 \mathrm{~b}$ & $12.77 \mathrm{~b}$ & $13.78 \mathrm{bc}$ \\
\hline G. intraradices & $3.97 \mathrm{a}$ & $4.93 \mathrm{a}$ & $11.57 \mathrm{a}$ & $15.90 \mathrm{a}$ & $19.01 \mathrm{a}$ \\
\hline A. mellea & $4.07 \mathrm{a}$ & $3.70 \mathrm{~b}$ & $6.04 \mathrm{c}$ & $8.88 \mathrm{c}$ & $11.85 \mathrm{c}$ \\
\hline $\begin{array}{l}\text { G. intraradices }+A . \text { mellea } \\
\text { Factor }\end{array}$ & $4.43 \mathrm{a}$ & $4.54 \mathrm{a}$ & $8.69 \mathrm{~b}$ & $11.81 \mathrm{~b}$ & $15.16 \mathrm{~b}$ \\
\hline Mycorrhiza & ns & $*$ & $*$ & $*$ & * \\
\hline Pathogen & ns & ns & $*$ & $*$ & $*$ \\
\hline Interaction & $\mathrm{ns}$ & ns & $\mathrm{ns}$ & ns & ns \\
\hline
\end{tabular}

Different letters in columns indicate significant differences $(p=0.05)$ according to Duncan's test. Mycorrhizal effect, pathogenic effect and the interaction between both factors were determined by a two way ANOVA. "*” and "ns" indicate significance $(p=0.05)$

roots, the most abundant PAs were putrescine and spermidine. Trace amounts of diaminopropane were also detected. In July 2005, 4 months after inoculation with $G$. intraradices, when the mycorrhizal root colonisation was under $50 \%$, the total root free PA content was significantly higher in $\mathrm{M}$ plants compared to NM plants (Fig. 1, Table 5). Polyamine increase in symbiotic roots was mainly due to putrescine (Fig. 1). However, 1 month later, when the mycorrhizal colonisation was above $50 \%$ there were no significant differences in total root free PAs (Fig. 1). At sprouting-time of the second growing year (March 2006), the mycorrhizal effect was not detected in total root PA content and a drastic PA decrease was observed in all treatments (Table 5, Fig. 1).

In leaves, spermine was also detected (Fig. 2). Polyamine concentration decreased in all treatments at the end of the growing season, and increased again at sprouting-time. Significantly higher levels of total leaf PAs (mainly putrescine) were detected at such

Table 4 Mycorrhizal colonisation in plants inoculated with $G$. intraradices during the first and the second growing year

\begin{tabular}{lll}
\hline Sampling dates & \multicolumn{2}{c}{ Mycorrhizal colonisation (\%) } \\
\cline { 2 - 3 } & G. intraradices & G. intraradices + A. mellea \\
\hline July 2005 & $47 \pm 4.5$ & $40 \pm 13.8$ \\
August 2005 & $75 \pm 3.9$ & $65 \pm 8.7$ \\
September 2005 & $62 \pm 3.3$ & $57 \pm 5.9$ \\
March 2006 & $70 \pm 5.0$ & $76 \pm 0.8$ \\
October 2006 & $78 \pm 3.4$ & $76 \pm 5.2$
\end{tabular}

Data are means $\pm \mathrm{SE}$ of three samples from different plants developmental stages in M-pathogen-free plants (Table 5, Fig. 2).

When A. mellea was present, PA content in $\mathrm{M}$ or NM plants varied along time. Pathogen-infected plants not associated to AMF showed a significant decrease in leaf PA levels from the third week after inoculation until the sprouting time (Table 5). In contrast, total PA content in leaves of M-pathogeninfected plants was higher compared to NM plants and reached the control values. Nevertheless, although at the end of the growing season $\mathrm{M}-A$. mellea plants presented slightly higher PA levels, the differences were not significant. These variations were especially due to both putrescine and spermidine (Fig. 2).

\section{Discussion}

The ability of AM to enhance grapevine growth has been described by several authors (Bavaresco and Fogher 1996; Camprubí et al. 2008; Karagiannidis et al. 1995; Waschkies et al. 1994), and accordingly, in the present work a positive effect of AMF on root and shoot biomass of vine plants was observed. Moreover, a good growth response to the inoculation with G. intraradices BEG 72 was recorded in R-110 (Camprubí et al. 2008). Although the pathogen produced a growth decrease in our R-110 vine plants inoculated with $A$. mellea, a positive effect of the AMF on their growth was observed. Our results confirm the findings of previous research showing the susceptibility of the rootstock R-110 to A. mellea 
Fig. 1 Root total free polyamines, putrescine $(P u t)$ and spermidine $(\mathrm{Spm})$ in mycorrhizal or non mycorrhizal Richer 110 vines infected or not with Armillaria mellea. Means+SE of three samples obtained from different plants. Different letters indicate significant differences between treatments at $p=0.05$

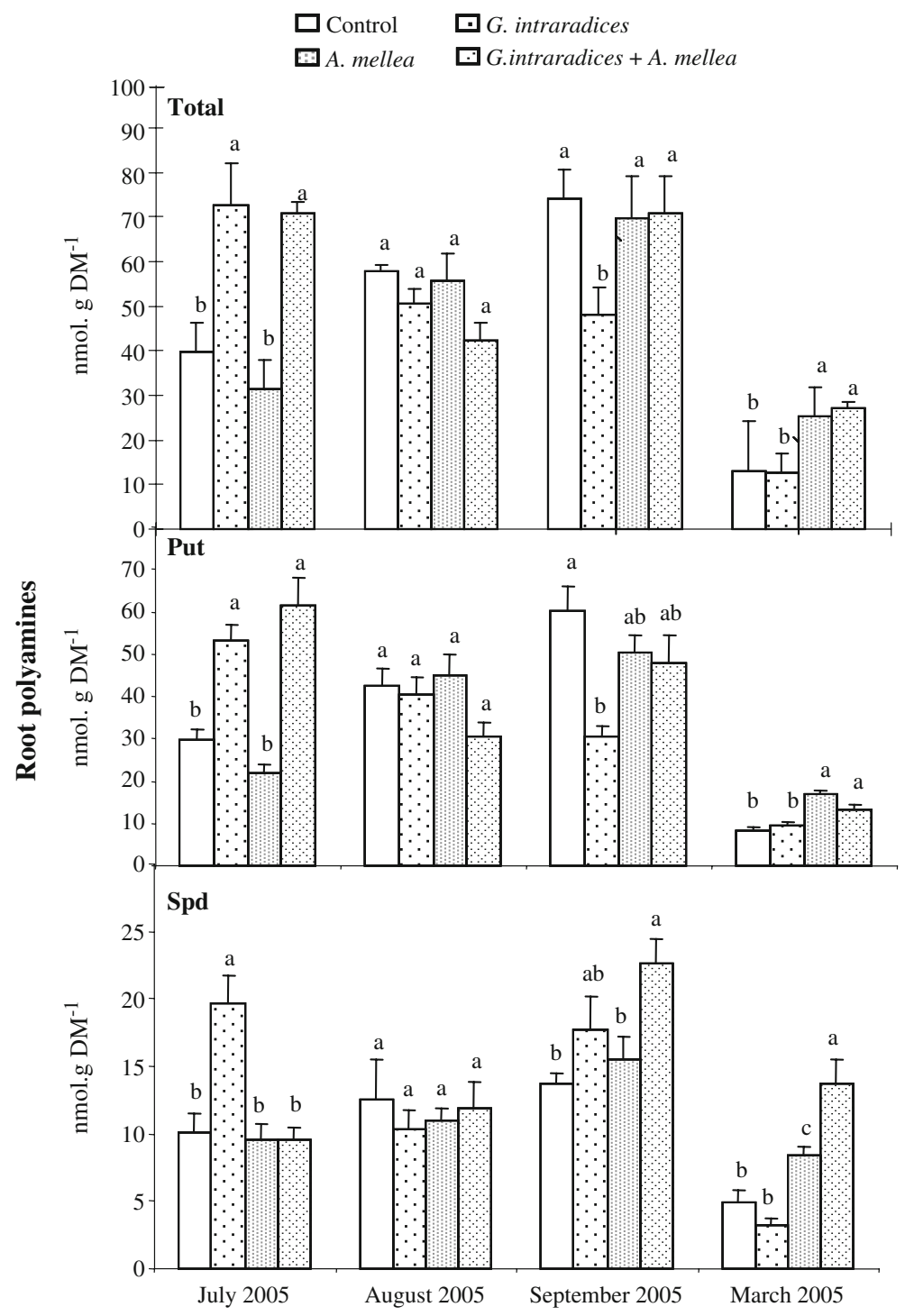

(Baumgartner and Rizzo 2006), and the increased tolerance due to the artificial mycorrhizal inoculation (Aguín-Casal et al. 2006).

Recorded data related to root disease, such as percentage of root infection and percentage of plant mortality of infected plants, are difficult to apply to Armillaria root disease, as mycelial fans grow beneath the bark of woody roots, making it difficult to quantify signs of $A$. mellea and infection extent. It has been demonstrated that grapevines with obvious foliar symptoms of Armillaria root disease (dwarfed leaves, wilting, and premature defoliation) produce lower yield and plant growth decreases when compared with healthy grapevines (Raabe 1988;
Baumgartner 2004). It has been proposed (Baumgartner 2004) that alleviation of pathogen impact on plant yield and growth could be used as a measure of the efficacy of control methods of Armillaria root disease. The improved growth in M plants inoculated with the pathogen could be due to a better compensation for the damage caused by the pathogen (Aguin-Casal et al. 2006; Pozo et al. 2002) or to changes in mycorrhizal root architecture that may provide fewer sites for infection (Fusconi et al. 1999; Norman et al. 1996). At the end of the second growing year, although the pathogen caused a decrease in aerial and root biomass, plants associated to AMF grew significantly better indicating that 
Table 5 Effects of mycorrhiza, pathogen and the interaction between both factors in root and leaf free polyamine levels in R-110 vines inoculated or not with Glomus intraradices and infected or not with Armillaria mellea

\begin{tabular}{|c|c|c|c|c|c|}
\hline \multirow[t]{2}{*}{ Polyamine } & \multirow[t]{2}{*}{ Factor } & \multicolumn{4}{|c|}{ Sampling date } \\
\hline & & July 2005 & August 2005 & September 2005 & March 2006 \\
\hline \multirow[t]{3}{*}{ Root total PAs } & Mycorrhiza & $*$ & ns & ns & ns \\
\hline & Pathogen & ns & ns & ns & $*$ \\
\hline & Interaction & ns & ns & $*$ & ns \\
\hline \multirow[t]{3}{*}{ Root putrescine } & Mycorrhiza & $*$ & ns & $*$ & ns \\
\hline & Pathogen & ns & ns & ns & $*$ \\
\hline & Interaction & ns & ns & $*$ & $*$ \\
\hline \multirow[t]{3}{*}{ Root spermidine } & Mycorrhiza & $*$ & ns & $*$ & ns \\
\hline & Pathogen & $*$ & ns & ns & $*$ \\
\hline & Interaction & $*$ & ns & ns & $*$ \\
\hline \multirow[t]{3}{*}{ Leaf total PAs } & Mycorrhiza & ns & $*$ & ns & $*$ \\
\hline & Pathogen & $*$ & $*$ & $*$ & $*$ \\
\hline & Interaction & ns & ns & ns & $*$ \\
\hline \multirow[t]{3}{*}{ Leaf putrescine } & Mycorrhiza & $*$ & ns & $*$ & $*$ \\
\hline & Pathogen & $*$ & $*$ & $*$ & $*$ \\
\hline & Interaction & $*$ & ns & $*$ & $*$ \\
\hline \multirow[t]{3}{*}{ Leaf spermidine } & Mycorrhiza & ns & $*$ & ns & $*$ \\
\hline & Pathogen & $*$ & $*$ & ns & $*$ \\
\hline & Interaction & ns & ns & ns & $*$ \\
\hline \multirow[t]{3}{*}{ Leaf spermine } & Mycorrhiza & ns & ns & $*$ & $*$ \\
\hline & Pathogen & $*$ & ns & $*$ & $*$ \\
\hline & Interaction & $*$ & $*$ & $*$ & $*$ \\
\hline
\end{tabular}

“*” and "ns" indicate significance at 0.05 probability levels, or not significant, respectively, according to Duncan's test

AMF inoculation alleviated disease symptoms. This improvement was confirmed by the survival of plants and slower appearance of necrotic symptoms in roots and root collar when mycorrhizal plants were inoculated with the pathogen.

When the mycorrhizal colonisation percentage was above $50 \%$ the symbiosis was considered to be well established, although the extent of root colonisation in grapevines depends on the rootstock and on the fungal species. It has been observed that the percentage of root colonisation achieved with Glomus mosseae in R-110 rootstock plants was from $57 \%$ to $77 \% 3$ years after AMF inoculation (Karagiannidis et al. 2007), and with $G$. intraradices it was around $60 \%$ 4 months after inoculation (Camprubi et al. 2008). Therefore, in the first sampling-date (July, 2005), the symbiosis was not fully established. El Ghachtouli et al. (1995) suggested that PAs may play a role in AMF establishment and in initial steps of the infection by G. intraradices, since they particularly stimulated infection frequency of the root system in pea plants. In our case, in July 2005, M plants showed higher free PA content than NM ones and the increase detected in root PAs, especially putrescine, might be related to the AMF establishment. In fact, El Ghachtouli et al. (1996) observed that the biosynthetic enzyme of putrescine, ornithine decarboxilase (EC 4.1.1.17), played an important role in root growth and in AMF development.

When root colonisation was above 50\% (August, 2005), PAs did not show a clear pattern following mycorrhizal symbiosis, neither in roots nor in leaves. The information available about free PA content in M plants when the symbiosis is well established is controversial. Most studies (Goicoechea et al. 1998; Paradi et al. 2003; Sannazzaro et al. 2007) show variations in PAs, but they do not clarify the significance of those changes. Obviously, further studies should be conducted in order to understand the meaning of PA variations and to elucidate the role of free PAs during the development of the mycorrhizal symbiosis.

By contrast, in plants infected by A. mellea a higher concentration of free PAs (both putrescine and spermidine) was observed 9 months after the inoculation with the pathogen (October, 2006), when the 
Fig. 2 Leaf total free polyamine, putrescine $(P u t)$ spermidine $(\mathrm{Spm})$ and spermine $(\mathrm{Spm})$. Means $+\mathrm{SE}$ of three samples obtained from different plants. Different letters indicate significant differences between treatments at $p=0.05$

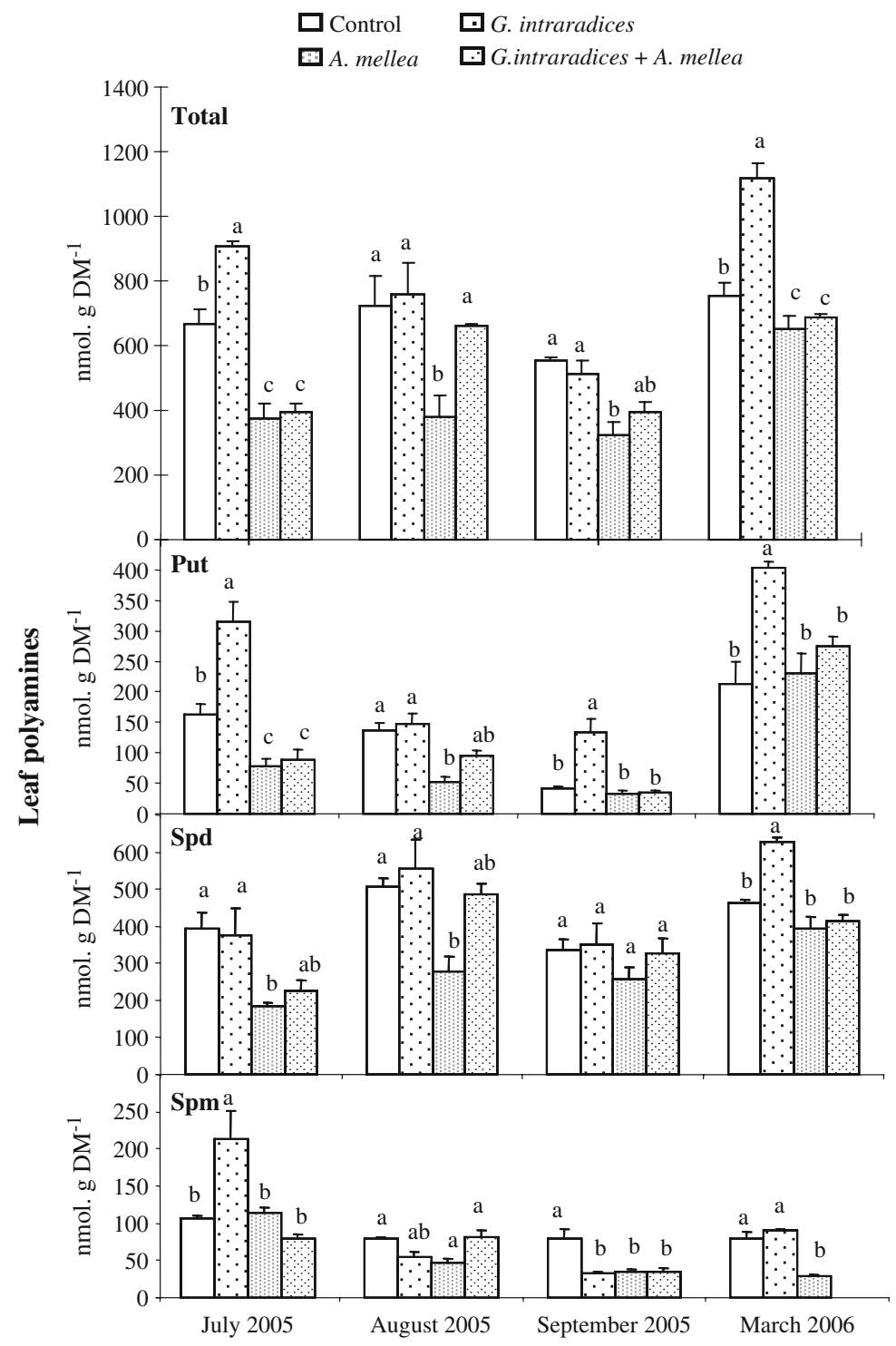

symptoms of the disease were already quite advanced. Pathogenic infections induce important modifications in plant PAs (Darrieumerlou et al. 2001; Paschaladis et al. 2001; Rifai et al. 2005), that vary depending on several factors such as the nature of analyzed plant tissues, that can be locally infected or not by the pathogen, and the degree of plant tolerance to the disease.

It is probable that the increase in PA levels observed in grapevine roots infected by $A$. mellea could have a fungal origin. The presence of fungal free PAs has been reported in several pathosystems (Darrieumerlou et al. 2001; Foster and Walters 1990; Koussa et al.
1997; Rajam and Rajam 1996). As low PA levels are a characteristic of senescent tissues with low cellular division activity (Torrigiani et al. 1989), and in grapevine plants infected with $A$. mellea necrotic tissues were observed, the unexpected increase of PA concentration should be caused by the pathogen.

On the other hand, in leaves of $A$. mellea-infected plants a decrease in Put and Spd was observed since the third week after the pathogen's inoculation. Probably, fungal PAs would not be transported out of the infected organ (Rifai et al. 2005), so all the fluctuations observed in grapevine leaves would be a plant response to the root pathogen. 
Several authors (Belles et al. 1991; Edreva 1997; Rifai et al. 2004) also observed a lower concentration of free PAs as a consequence of pathogenic infections. It has been suggested that PAs decrease in these interactions is a non-specific response to tissue damage or to a senescent status of leaves (Edreva 1997; Rifai et al. 2004), as low PA levels are often characteristic of tissues where metabolism has slowed down (Galston and Kaur-Sawhney 1990).

It is not clear if the changes in polyamine metabolism are the primary response to the stress or if they are caused indirectly via the effects of the stress on other physiological processes through signal transduction (Minocha et al. 1997), or if they may be implicated in signalization of plant pathogen interactions (Martin-Tanguy 1987; Whipps et al. 1982). The drastic PA decrease observed in leaves three weeks after inoculation with the pathogen, even before any external symptom was apparent, indicates that plant metabolism was altered very early because of the infection. This suggests that PAs could be involved in the signalling of pathogenic events. Minocha et al. (1997) already demonstrated that changes in polyamine levels in response to stress could possibly be used as an early warning tool for assessing and predicting tree health before the appearance of visual symptoms.

One month after the decrease in PAs in plants infected with A. mellea, the leaf PA pattern in M and NM plants became different depending on the presence of the pathogen. In M plants infected with the pathogen a subsequent PA increase was observed (Table 5, Fig. 2). This reaction may be an early signal of mycorrhizal plants to initiate defence mechanisms. It has been observed that PAs are modified in a different way in resistant and susceptible tobacco plants to the tobacco mosaic virus (Guo et al. 1999), and it has also been demonstrated that they are implicated in the resistance development against Ascochyta rabiei in chickpea (Angellini et al. 1993).

The slower development of pathogenic symptoms in $\mathrm{M}$ plants and the greater growth of shoot and roots when compared to the NM plants inoculated with $A$. mellea, indicate that $\mathrm{M}$ plants are more tolerant to the pathogen than NM plants. The early changes in PA levels detected in A. mellea inoculated plants, and the sudden increase observed in those levels at the beginning of the infection in $\mathrm{M}$ plants suggest that PAs would be implicated in the early signalling processes of the tolerance increase of $\mathrm{M}$ plants against the pathogen.

Acknowledgements Financial support for this research was provided by the Instituto de Investigación y Tecnología Agraria y Alimentaria (INIA), project RTA-04-027-C2-1, by the "Departament d'Universitats, Recerca i Societat de la Informació de la Generalitat de Catalunya" and by the European Regional Development Fund.

\section{References}

Agrios GN (2005) How plants defend themselves against pathogens. In: Agrios, GN (eds) Plant pathology. 5th edn. Academic, San Diego, pp 98-117

Aguín O (2001) Detección, identificación y control de Armillaria mellea (Vahl: Fr.) Kummer en vid. PhD Thesis. Universidad de Santiago de Compostela, Departamento de Producción Vegetal.

Aguín O, Mansilla JP, Vilariño A, Sainz MJ (2004) Effects of mycorrhizal inoculation on root morphology and nursery production of three grapevine rootstocks. Am J Enol Vitic 55:108-111

Aguín-Casal O, Montenegro D, Mansilla JP (2006) Protección de la vid frente a Armillaria mellea mediante la aplicación de hongos micorrícicos. Nutri-Fitos 163:27-33

Alcázar R, Altabella T, Tiburcio AF (2003) Las poliaminas. In: Reigosa MJ, Pedrol N, Sanchez-Moreiras A (eds) La Ecofisiología vegetal. Una ciencia de síntesis. Paraninfo S. A. pp 725-747

Angellini R, Bragaloni M, Federico R, Infantion A, PortaPuglia A (1993) Involvement of polyamines, diamine oxidase and peroxidase in resistance of chickpea to Ascochyta rabiei. J Plant Physiol 142:704-709

Azcón-Aguilar C, Jaizme-Vega MC, Calvet C (2002) The contribution of arbuscular mycorrhizal fungi to the control of soil-borne plant pathogens. In: Gianinazzi, S, Schüepp, H, Barea, JM, Haselwandter, K (eds) Mycorrhizal technology in agriculture. Birkhäuser Verlag, Switzerland, pp 187-197

Baumgartner K (2004) Root collar excavation for postinfection control of Armillaria root disease of grapevine. Plant Dis 88:1235-1240 doi:10.1094/PDIS.2004.88.11.1235

Baumgartner K, Rizzo DM (2006) Relative resistance of grapevine rootstocks to Armillaria root disease. Am J Enol Vitic 57:408-414

Baumgartner K, Warnock AE (2006) A soil inoculant inhibits Armillaria mellea in vitro and improves productivity of grapevines with root disease. Plant Dis 90:439-444 doi:10.1094/PD-90-0439

Baumgartner K, Smith RF, Bettiga L (2005) Weed control and cover crop management affect mycorrhizal colonisation of grapevine roots and arbuscular mycorrhizal fungal spore populations in a California vineyard. Mycorrhiza 15:111119 doi:10.1007/s00572-004-0309-2

Bavaresco L, Fogher C (1996) Lime induced chlorosis of grapevine as affected by rootstock and root infection with arbuscular mycorrhiza and Pseudomonas fluorescens. Vitis 35:119-123 
Beckman TG, Pusey PL (2001) Field testing peach rootstocks for resistance to Armillaria root rot. HortScience 36:101-103

Belles JM, Perez-Amador MA, Carbonell J, Conejero V (1991) Polyamines in plant infected by citrus exocortis viroid or treated with silver ions and ethephon. Plant Physiol 96:1053-1059

Bouchereau A, Aziz A, Larher F, Martin-Tanguy J (1999) Polyamines and environmental challenges: recent development. Plant Sci 140:103-125 doi:10.1016/S0168-9452 (98)00218-0

Calvet C, Pinochet J, Camprubí A, Fernández C (1995) Increased tolerance to the root-lesion nematode Pratylenchus vulnus in mycorrhizal micropropagated BA-29 quince rootstock. Mycorrhiza 5:253-258

Camprubí A, Estaún V, Nogales A, García-Figueres F, Pitet M, Calvet C (2008) Response of the grapevine rootstock Richter 110 to inoculation with native and selected arbuscular mycorrhizal fungi and growth performance in a replant vineyard. Mycorrhiza 18:211-216 doi:10.1007/ s00572-008-0168-3

Cheng X, Baumgartner K (2006) Effects of mycorrhizal roots and extraradical hyphae on $15 \mathrm{~N}$ uptake from vineyard cover crop litter and the soil microbial community. Soil Biol Biochem 38:2665-2675 doi:10.1016/j.soilbio.2006.03.023

Darrieumerlou A, Geny L, Broquedis M, Donèche B (2001) Évolution de la composition en polyamines des baies de raisin au cours du processus d'infection par Botrytis cinerea. Vitis 40:11-15

Edreva A (1997) Tobacco polyamines as affected by stresses induced by different pathogens. Biol Plant 40:317-320 doi:10.1023/A:1001093209229

El Ghachtouli N, Paynot M, Morandi D, Martin-Tanguy J, Gianinazzi S (1995) The effect of polyamines on endomycorrhizal infection of wildtype Pisum sativum, cv. Frisson (nod + myc + ) and two mutants (nod-myc +and nod-myc-). Mycorrhiza 5:189-192

El Ghachtouli N, Martin-Tanguy J, Paynot M, Gianinazzi S (1996) First report of the inhibition of Pisum sativum by specific and irreversible inhibition of polyamine biosynthesis or by gibberellic acid treatment. FEBS Lett 385:189-192 doi:10.1016/0014-5793(96)00379-1

Flores HE, Galston AW (1982) Analysis of polyamines in higher plants by high performance liquid chromatography. Plant Physiol 69:701-706

Foster SA, Walters DR (1990) The effects of polyamine biosynthesis inhibitors on mycelial growth, enzyme activity and polyamine levels in the oat-infecting fungus Pyrenophora avenae. J Gen Microbiol 136:233-239

Fox RTV (2003) Managing Armillaria root rot. Food Agric Environ 95:95-100

Fusconi A, Gnavi E, Trotta A, Berta G (1999) Apical meristems of tomato roots and their modifications induced by arbuscular mycorrhizal and soilborne pathogenic fungi. New Phytol 142:505-516 doi:10.1046/j.14698137.1999.00410.x

Galston AW, Kaur-Sawhney RK (1990) Polyamines in plant physiology. Plant Physiol 94:406-410

Geny L, Broquedis M, Martin-Tanguy J, Bouard J (1997) Free, conjugated and wall-bound polyamines in various organs of fruiting cuttings of Vitis vinifera cv. Cabernet-Sauvignon. Am J Enol Vitic 48:80-84
Giovannetti M, Mosse B (1980) An evaluation of techniques for measuring vesicular arbuscular mycorrhizal infection in roots. New Phytol 84:489-500 doi:10.1111/j.14698137.1980.tb04556.x

Goicoechea N, Szalai G, Antolín MC, Sánchez-Díaz M, Paldi E (1998) Influence of arbuscular mycorrhizae and Rhizobium on free polyamines and proline levels of water-stressed alfalfa. J Plant Physiol 153:706-711

Guo X, Li G, Shang Z, Li X, Liu Y (1999) Relationship between free polyamines and resistance of tobacco to TMV. Hebei Nongye Daxue Xuebao 22:32-35

Karagiannidis N, Nikolaou N, Matheou A (1995) Influence of three VA-mycorrhiza species on the growth and nutrient uptake of three grapevine rootstocks and one table grape cultivar. Vitis 34:85-89

Karagiannidis N, Nikolaou N, Ipsilantis I, Zioziou E (2007) Effects of different $\mathrm{N}$ fertilizers on the activity of Glomus mosseae and on grapevine nutrition and berry composition. Mycorrhiza 18:43-50 doi:10.1007/s00572-007-0153-2

Kaur-Sawhney R, Tiburcio AF, Altabella T, Galston A (2003) Polyamines in plants: an overview. J Cell Mol Biol 2:1-12

Khaosaad T, García-Garrido JM, Steinkellner S, Vierheilig H (2007) Take-all disease is systemically reduced in roots of mycorrhizal barley plants. Soil Biol Biochem 39:727-734 doi:10.1016/j.soilbio.2006.09.014

Koske RE, Gemma JH (1989) A modified procedure for staining roots to detect VA mycorrhizas. Mycol Res 92:486-505

Koussa T, Broquedis M, Dubos B (1997) Relation possible entre l'agressivité de deux souches d'Eutypa lata et leur contenu en polyamines et en acide abscissique. J Int Sci Vigne Vin 31:153-156

Li HY, Yang GD, Shu HR, Yang YT, Ye BX, Nishida I et al (2006) Colonisation by the arbuscular mycorrhizal fungus Glomus versiforme induces a defence response against the root-knot nematode Meloidogyne incognita in the grapevine (Vitis amurensis Rupr.), which includes transcriptional activation of the class III chitinase gene VCH3. Plant Cell Physiol 47:154-163 doi:10.1093/pcp/pci231

Liu J, Maldonado-Mendoza I, López-Meyer M, Cheung F, Town CD, Harrison MJ (2007) Arbuscular mycorrhizal symbiosis is accompanied by local and systemic alterations in gene expression and an increase in disease resistance in the shoots. Plant J 50:529-544 doi:10.1111/ j.1365-313X.2007.03069.x

Ludwig-Müller J (2000) Hormonal balance in plants during colonisation by mycorrhizal fungi. In: Kapulnik, K, Douds, DD (eds) Arbuscular mycorrhizas: physiology and function. Kluwer Academic, Netherlands, pp 263-285

Martin-Tanguy J (1987) Hydroxycinnamic acid amides, hypersensitivity, flowering and sexual organogenesis in plants. In: Wettstein, D, Chua, DN (eds) Plant molecular biology. Plenum, New York, pp 253-263

Menge JA, Raski DJ, Lider LA, Johnson ELV, Jones NO, Kissler JJ (1983) Interactions between mycorrhizal fungi, soil fumigation, and growth of grapes in California. Am J Enol Vitic 34:117-121

Minocha R, Shortle WC, Lawrence GB, David MB, Minocha SC (1997) Relationships among foliar chemistry, foliar polyamines, and soil chemistry in red spruce trees growing across the northeastern United States. Plant Soil 191:109122 doi:10.1023/A:1004293523185 
Ndayiragije A, Lutts S (2007) Long term exogenous putrescine application improves grain yield of a salt-sensitive rice cultivar exposed to NaCl. Plant Soil 291:225-238 doi:10.1007/s11104-006-9188-y

Nikolaou N, Angelopoulos K, Karagiannidis N (2003) Effects of drought stress on mycorrhizal and non-mycorrhizal Cabernet Sauvignon grapevine, grafted onto various rootstocks. Exp Agric 39:241-252 doi:10.1017/ S001447970300125X

Norman JR, Atkinson D, Hooker JE (1996) Arbuscular mycorrhizal fungal-induced alteration to root architecture in strawberry and induced resistance to the root pathogen Phytophthora fragariae. Plant Soil 185:191-198 doi:10.1007/BF02257524

Paradi I, Bratek Z, Láng F (2003) Influence of arbuscular mycorrhiza and phosphorus supply on polyamine content, growth and photosynthesis of Plantago lanceolata. Biol Plant 46:563-569 doi:10.1023/A:1024819729317

Paschaladis KA, Aziz A, Geny L, Primikirios NI, RoubelakisAngelakis KA (2001) Polyamines in grapevine. In: Roubelakis-Angelakis, KA (eds) Molecular biology \& biotechnology of the grapevine. Kluwer Academic, Netherlands, pp 109-151

Pozo MJ, Cordier C, Dumas E, Gianinazzi S, Barea JM, Azcón-Aguilar C (2002) Localized vs systemic effect of arbuscular mycorrhizal fungi on defence responses to Phytophthora infection on tomato plants. J Exp Bot 53:525-534 doi:10.1093/jexbot/53.368.525

Raabe R (1988) Armillaria root rot. In: Pearson, RC, Goheen, $\mathrm{AC}$ (eds) Compendium of grape diseases. American Phytopathological Society, St. Paul, MN, pp 35-36

Rajam B, Rajam MV (1996) Inhibition of polyamine biosynthesis in plant pathogenic fungi in vitro. Mycopathologia 133:95-103 doi:10.1007/BF00439120

Rifai LA, Koussa T, Geny L, Fassouane A, Dubos B, Broquedis M (2004) Évolution des teneurs en polyamines dans les fleurs et les jeunes baies de Vitis vinifera L. (cv. Cabernet Sauvignon) atteints d'eutypiose. Vitis 43:139-144

Rifai LA, Koussa T, Geny L, Fassouane A, Broquedis M, Dubos B (2005) Évolution des teneurs en polyamines libres et conjuguées dans les feuilles de vigne (Vitis vinifera "Cavernet Sauvignon") saine et atteinte d'eutypiose. Can J Bot 83:194-201 doi:10.1139/b04-165

Rishbeth J (1976) Chemical treatment and inoculation of hardwood stumps for control of Armillaria mellea. Ann Appl Biol 82:57-70 doi:10.1111/j.1744-7348.1976. tb01672.x

Sannazzaro AI, Echeverria M, Alberto EO, Ruiz OA, Menendez AB (2007) Modulation of polyamine balance in Lotus glaber by salinity and arbuscular mycorrhiza. Plant Physiol Biochem 45:39-46 doi:10.1016/j.plaphy.2006.12.008

Torrigiani P, Serafini-Fracassini D, Fara A (1989) Diamine oxidase activity in different physiological stages of Helianthus tuberosus tuber. Plant Physiol 89:69-73

Walters DR (2000) Polyamines in plant-microbe interactions. Physiol Mol Plant Pathol 57:137-146 doi:10.1006/ pmpp. 2000.0286

Waschkies C, Schropp A, Marschner H (1994) Relations between grapevine replant disease and root colonisation of grapevine (Vitis sp.) by fluorescent pseudomonads and endomycorrhizal fungi. Plant Soil 162:219-227 doi:10.1007/BF01347709

Whipps JM, Haselwandter K, MCGee EEM, Lewis DH (1982) Use of biochemical markers to determine growth, development and biomass of fungi in infected tissues, with particular reference to antagonistic and mutualistic biotrophs. Trans Br Mycol Soc 79:785-400

Wróbel-Kwiatkowska M, Lorenc-Kukula K, Starzycki M, Oszmianski J, Kepczynska E, Szopa J (2004) Expression of $\beta$-1,3-glucanase in flax causes increased resistance to fungi. Physiol Mol Plant Pathol 65:245-256 doi:10.1016/j. pmpp.2005.02.008 